\title{
Laboratory Test Methods for Assessing the Abrasivity of Rocks and Soils in Geotechnology and Mining Applications
}

\section{Laboratorijske preiskave abrazivnosti kamnin in zemljin na področju geotehnologije in rudarstva}

\author{
B. Janc*, V. Jovičić, Ž. Vukelić \\ University of Ljubljana, Faculty of Natural Sciences and Engineering, Department of Geotechnology, Mining and Environment, \\ Aškerčeva 12, Ljubljana, Slovenia \\ * blaz.janc@ntf.uni-lj.si
}

\begin{abstract}
In geotechnology and mining, tools and equipment interact with aggressive geological material, causing the wear of these components. For this reason, it is important to determine the rate of abrasivity of individual geological materials, depending on the type of interaction with the tool. Various abrasivity tests have been developed in laboratories. Some of them are general, while others are special. What they all have in common is that they attempt to determine the abrasivity of rocks or soils in relation to the wear of the test specimens. This article gives an overview of the laboratory test methods for assessing the abrasivity of geological materials, which are useful in the field of geotechnology and mining engineering. General and special abrasivity tests are presented in detail. The aim of the article is to present existing laboratory tests to assess the abrasivity of rocks and soils, based on which further investigations of wear can be considered as part of a comprehensive approach to this tribological problem. Understanding of the wear mechanisms is the basis for the development of wear-resistant tools and models for predicting the tool life.
\end{abstract}

Key words: laboratory testing, abrasivity, wear, geotechnology, mining.

\section{Povzetek}

$\mathrm{V}$ geotehnologiji in rudarstvu so orodja in oprema $\mathrm{v}$ interakciji z agresivnim geološkim materialom, ki povzroča obrabo omenjenih komponent. Zaradi tega obstaja težnja po določevanju stopnje abrazivnosti posameznih geoloških materialov glede na vrsto interakcije $\mathrm{z}$ orodjem. V laboratorijih so bile razvite različne preiskave abrazivnosti. Ene od njih so splošne, druge namenske. Vsem pa je skupno to, da skušajo določiti abrazivnost kamnin ali zemljin glede na obrabo preizkušanca. $\mathrm{V}$ članku je predstavljen pregled laboratorijskih preiskav abrazivnosti geoloških materialov, ki so uporabne na področju geotehnologije in rudarstva. Splošne in namenske preiskave abrazivnosti so podrobno predstavljene. Namen članka je predstaviti obstoječe laboratorijske preiskave abrazivnosti kamnin in zemljin, na podlagi katerih je mogoče nadaljnje preiskovanje obrabe kot del celovitega pristopa pri tem tribološkem problemu. Razumevanje mehanizmov obrabe je podlaga za razvijanje orodij, odpornih proti obrabi ter modelov za napovedovanje njihove življenjske dobe.

Ključne besede: laboratorijsko preiskovanje, abrazivnost, obraba, geotehnologija, rudarstvo 


\section{Introduction}

Geotechnology as an engineering discipline is confronted with many cases in which tools and equipment in dynamic contact with geological material get worn out. They are exposed to high compression, shear and impact loads. The result of these loads is material damage to the tools and equipment used in the technological process, which gradually reduces their functionality.

The areas of geotechnology where the wear of tools and equipment are most pronounced (Figure 1) can be divided into the following four main groups:

1) Tunnelling

2) Drilling

3) Mining

4) Mineral processing

The first group includes the tunnelling sector, which deals with the construction of road and rail tunnels, as well as tunnels for water transport and sewerage. Tunnelling can be carried out conventionally by drilling and blasting or mechanised with tunnel boring machines (TBMs) or excavation machines (roadheaders). Both the excavation methods lead to tool wear. In the conventional method, the drill bits are worn out when drilling boreholes, whereas in the mechanised method the disc cutters on the TBM or the teeth on the head of the excavation machine (roadheader) are worn out.

The second group includes the drilling sector, which deals with the drilling of production, exploratory or technical boreholes. Production wells are intended for the production of minerals and energy, such as oil, gas and geothermal energy. Exploratory boreholes are used for geological-geomechanical investigations. Technical boreholes are used for rock blasting and anchoring geotechnical constructions. All these operations, during which percussion or rotary drilling is performed, cause wear on the teeth or inserts of the drill bits, which are the main tool for drilling boreholes.

The third group includes the mining sector, which deals with the surface or underground extraction of mineral resources, including metals, non-metals and energy resources. In the mining sector, wear occurs mainly in two areas: the extraction and transport sectors. In the extraction sector, tools are worn on mechanised mining excavation machines such as the longwall shearer, continuous miner and bucket wheel excavator. In the transport sector, wear occurs on transport machines and equipment. The fourth group includes the mineral processing sector, which deals with the processing and preparation of mineral resources for use in various industrial processes. Most pronounced is the wear of equipment used to increase the specific surface area of the mineral resources. This includes crushing and grinding machines. Wear occurs on parts of the equipment that are in contact with the mineral. These are usually plates in various crushers and grinding media in mills.

In all the four groups described above, it is possible to find the occurrence of material wear that forms a tool or equipment that is in dynamic contact with geological material. In most cases, the materials of the tools and equipment are steels which, due to their wide availability and economic acceptance, currently have the most suitable wear resistance.

\section{Abrasivity and Tribological System}

Abrasivity plays an important role in the process of wear. It is a property that reflects the ability of a rock (geological material) to cause wear on materials [1]. The tribological system combines all components necessary for the wear process. These components are as follows:

1) Geological material

2) Tool material

3) Surrounding medium

4) Type of load (dynamic interaction)

A change in any of the above components also changes the mode and rate of wear. Figure 2 schematically shows a tribological system with all four components.

There are several methods for estimating the abrasivity of rocks and soils. In general, three categories can be distinguished [2]:

1) Indirect methods - assessment of abrasivity by a combination of different geomechanical properties such as hardness, uniaxial compressive strength, tensile strength and other fundamental properties. 


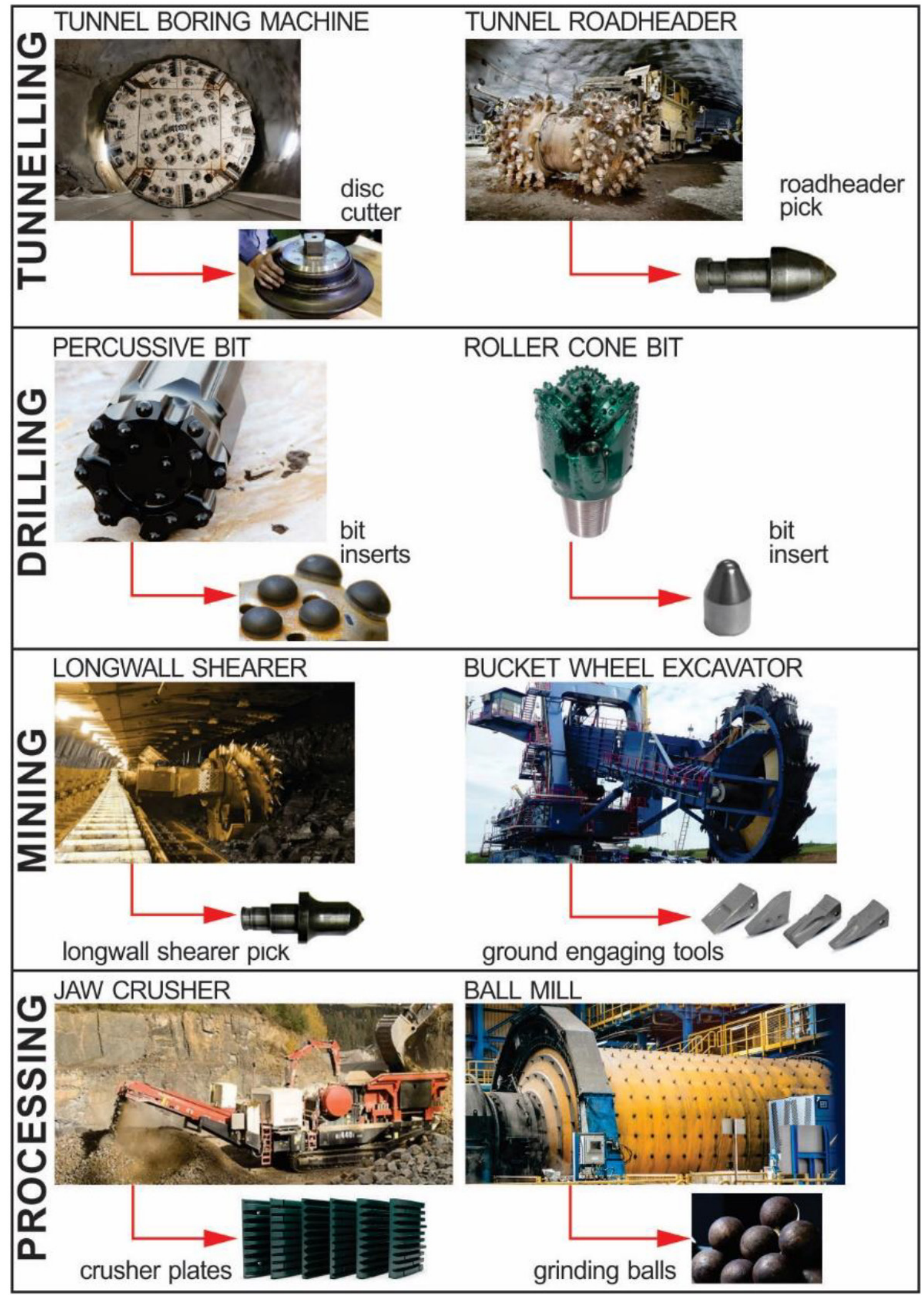

Figure 1: Wear of tools in geotechnology and mining engineering. The most typical devices for each field are shown (adapted from [3-16]). 


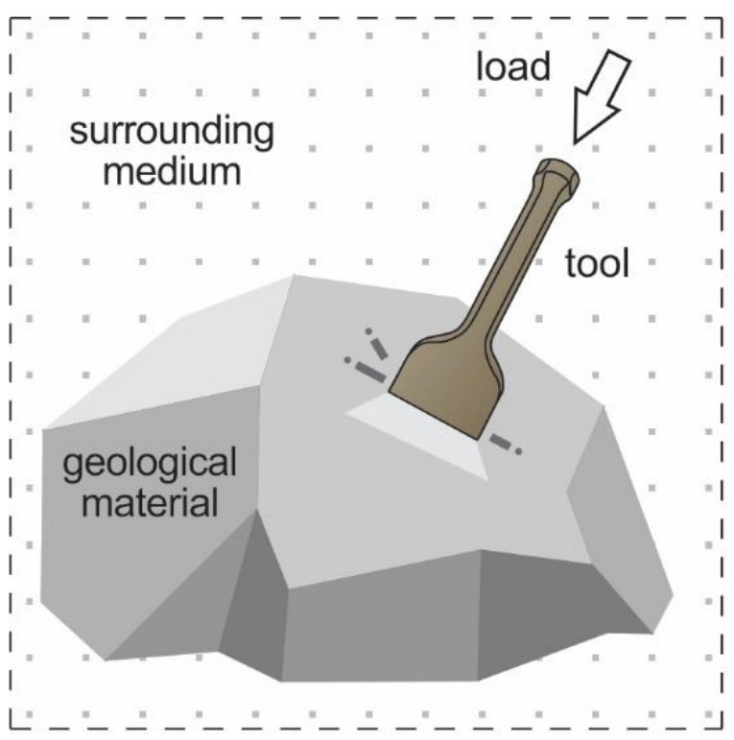

Figure 2: Tribological system (schematic).

2) Direct methods - assessment of abrasivity by laboratory test methods where there is relative movement between the geological sample and the wear tool in contact under the influence of controlled standard conditions.

3) Holistic methods - assessment of abrasivity by a combination of the fundamental geomechanical properties of the geological material and other parameters of the process and environment in which the wear occurs.

Indirect methods for assessing abrasivity have the advantage of using data that are already available or are relatively easy to obtain. However, they do not take into account the process variables for certain types of wear. Therefore, they are usually not used individually but in combination with direct or holistic methods.

The holistic methods for assessing abrasivity are very much related to certain equipment and processes and, therefore, have less value for other applications.

The direct methods for assessing abrasivity use the standard conditions to determine the abrasivity for a specific type of wear, either low or high stress or impact abrasion. The tests investigate the effects of relative movements between the geological sample and a wear tool in contact [2].

\section{Laboratory Test Methods for Assessing the Abrasivity of Geological Material}

Researchers have developed various laboratory devices to test the abrasivity of individual rocks and soils directly in the laboratory. The test methods differ depending on the design of the device or apparatus, the duration of the test, the method of causing wear, the shape and size of the abrasive material and the wear tool, and the purpose of the test. Some abrasivity tests are general and standardised to some extent. However, most of the tests are special and were intentionally developed for certain technological processes described in the introductory part of this article. It is worth noting that by far the largest number of abrasivity tests have been developed for mechanised tunnelling.

A general test method for assessing the abrasivity of geological material includes the CERCHAR abrasivity test for rocks and the LCPC abrasivity test for soils or grain materials. Both tests have been developed in France and are standardised. Special test methods for assessing the abrasivity of geological material are those developed for a specific application, such as tunnelling, drilling and mineral processing. The group of tests for tunnelling includes NTNU/SINTEF (AV, AVS and SAT ${ }^{\mathrm{TM}}$ ) and RIAT (rolling indentation abrasion test) abrasivity tests, which were developed for the estimation of tool wear in mechanised tunnelling. These abrasivity tests are not yet standardised. Miller abrasive test is used to determine the abrasivity of slurries and is standardised (ASTM G75 standard). The Gouging abrasion test can be used to estimate the wear of machine parts during crushing and grinding processes. The test is not standardised. It is also worth mentioning some other abrasivity tests that fall within the field of road construction. These are the (standardised) Los Angeles abrasion test, the Nordic ball mill test and the Dorry abrasion test, which all test the wear resistance of road aggregates.

\section{CERCHAR Abrasivity Test}

The CERCHAR abrasivity test was originally developed by a French laboratory (Laboratoire du Center d'Etudes et Recherches des Charbonnages de France) for mechanised coal mining. 
This method is described by two standards, the French standard AFNOR NF P 94-430-1 and the International standard ASTM D7625-10 [17].

\section{Apparatus}

There are two types of testing apparatus. The first is the original design as developed at the CERCHAR centre and the second is a modified design as reported by West [17].

In the CERCHAR apparatus (Figure 3), the loaded stylus moves across the surface of a stationary rock sample. In the case of the West design (Figure 4), however, the rock sample moves under the loaded stationary stylus. Different implementations of the apparatus design lead to a test duration [17].

Both apparatus have a rigid vice for firmly clamping the rock sample. Sufficient rigidity of the apparatus ensures that there is no lateral

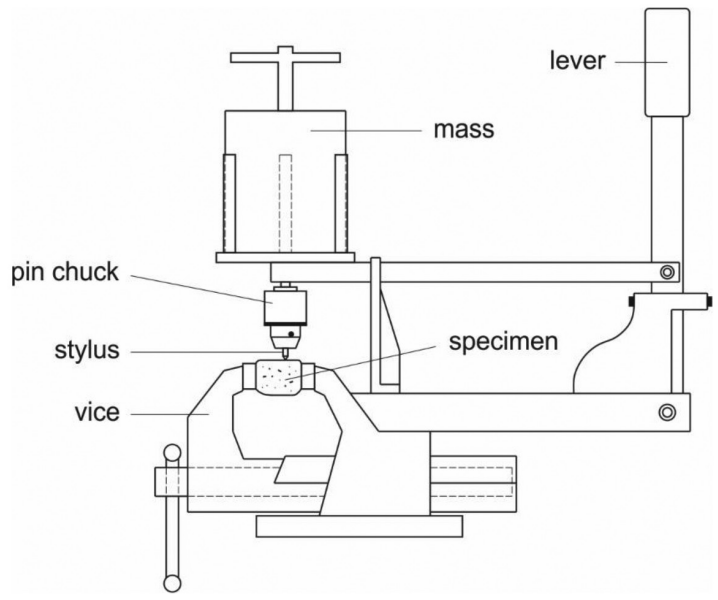

Figure 3: CERCHAR-type testing apparatus (adapted from [17]).

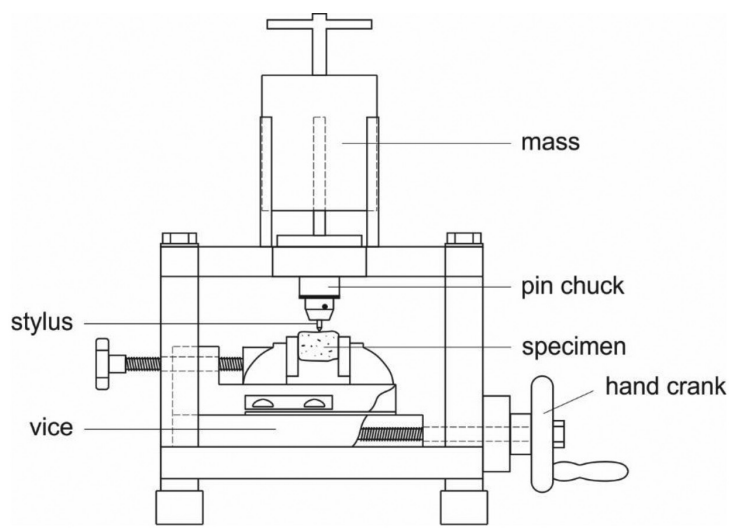

Figure 4: West-type testing apparatus (adapted from [17]). movement during the test. The stylus is loaded with a weight of $70 \mathrm{~N}$ [17].

\section{Stylus}

The stylus is made of standard chrome-vanadium cold-work tool steel and is hardened to Rockwell hardness HRC $55 \pm 1$. The stylus diameter should be at least $6 \mathrm{~mm}$. The length of the stylus should be such that the visible part of the stylus between the pin chuck and the surface of the rock sample is at least $15 \mathrm{~mm}$. The pin of the stylus (Figure 5) has a conical shape with an angle of $90^{\circ}$. The worn pin should be resharpened and examined under a microscope before being used for further testing [17]. a)

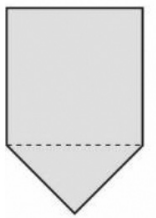

b)

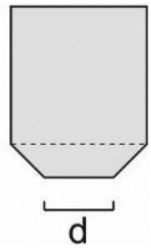

Figure 5: Steel pin. (a) Before the test. (b) After the test ( $d$ is the wear flat) (adapted from [18]).

\section{Test Sample}

The rock sample can be circular or irregularly shaped. A test on freshly broken rock surface is recommended. The rough surface can be obtained by a Brazilian tensile test (Figure 6) on the rock disc or by firm hammer blows on a rock core or rock sample. Alternatively, the sample can be prepared with a water-cooled diamond saw blade. The surface to be tested should be cleared of debris or loose grains of rock. The size of the rock surface should be suf-
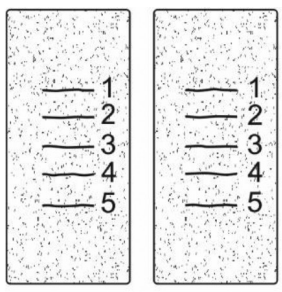

a)

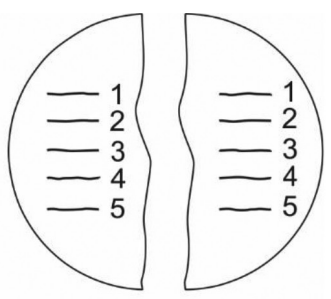

b)
Figure 6: The two halves of the sample disc with test scratches (1-5) after Brazilian tensile test. (a) Rough surface. (b) Smooth surface (adapted from [20]). 
ficient to allow five test scratches at a minimum distance of $5 \mathrm{~mm}$ and $5 \mathrm{~mm}$ from the edge of the rock surface [17].

\section{Test Procedure}

A microscopic inspection of the stylus should be performed before the test. The rock sample should be firmly clamped in the vice with the rock surface as horizontal as possible. The stylus should be carefully lowered onto the rock surface. The length of a test scratch in the rock sample must be exactly $10 \mathrm{~mm}$. Depending on the apparatus design used, the test duration is 1 (CERCHAR version) or $10 \mathrm{~s}$ (West version). The stylus pin must be in constant contact with the rock surface during the test [17]. The main parameters of the CERCHAR abrasivity test are summarised in Table 1.

Table 1: Main parameters of the CERCHAR abrasivity test.

\begin{tabular}{cc} 
Parameters & Value \\
\hline Load (N) & 70 \\
\hline $\begin{array}{c}\text { Stylus hardness } \\
\text { (HRC) }\end{array}$ & $55 \pm 1$ \\
\hline $\begin{array}{c}\text { Test scratch } \\
\text { length (mm) }\end{array}$ & 10 \\
\hline Sample material & Rock (freshly broken surface) \\
\hline $\begin{array}{c}\text { CERCHAR } \\
\text { (s) }\end{array}$ & WEST \\
\hline $\begin{array}{c}\text { Test result } \\
\text { CERCHAR abrasivity index } \\
\text { (CAI) }\end{array}$
\end{tabular}

At least five test repetitions must be carried out on the rock surface, each time with a new or resharpened pin [17].

\section{Stylus Wear Measurement}

The measurement of the length or diameter of the pin wear (d) is carried out with optical and digital methods (microscope). The measurement of the pin can be performed in the side or top view. However, it is recommended to measure in the side view [19]. Figure 7 shows the possible measurements of pin wear. When measuring in the top view, the mean value between $\mathrm{d}_{1}$ and $\mathrm{d}_{2}$ is taken for $\mathrm{d}$. a)

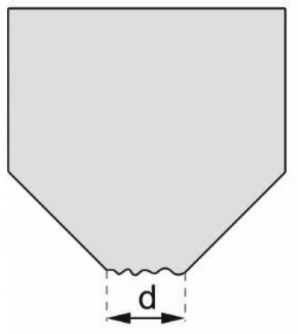

b)

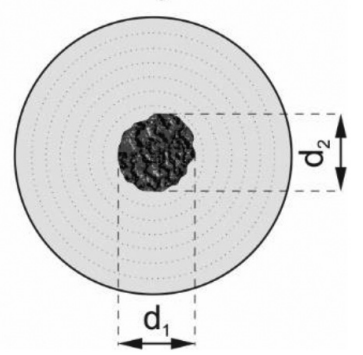

Figure 7: Measurements of pin wear. (a) Side view ( $d$ is the distance between the edges of the worn surface). (b) Top view ( $d_{1}$ and $d_{2}$ are diameters of the worn pin, measured from two orthogonal directions) (adapted from [17]).

\section{Calculation of CERCHAR Abrasivity Index}

For each measurement of pin wear (d), the CERCHAR abrasivity index (CAI) is calculated as

$C A I=d \times 10$

where $d$ is the length of the wear pin surface measured with an accuracy of $0.01 \mathrm{~mm}$ [17]. The dimensionless CAI value is given as the arithmetic mean of five or more test repetitions together with the standard deviation [17].

\section{Classification System}

The system for classifying abrasivity after ISRM [17] is given in Table 2. This system differs slightly from that proposed by the CERCHAR centre.

Table 2: Classification of the CERCHAR abrasivity index (CAI) [17].

\begin{tabular}{cc}
$\begin{array}{c}\text { Mean value } \\
\text { of CAI }\end{array}$ & $\begin{array}{c}\text { Classification/abrasivity } \\
\text { description }\end{array}$ \\
\hline $0.1-0.4$ & Extremely low \\
\hline $0.5-0.9$ & Very low \\
\hline $1.0-1.9$ & Low \\
\hline $2.0-2.9$ & Medium \\
\hline $3.0-3.9$ & High \\
\hline $4.0-4.9$ & Very high \\
\hline$\geq 5$ & Extremely high
\end{tabular}




\section{LCPC Abrasivity Test}

The LCPC abrasivity test was developed in the 1980s by a French laboratory (Laboratoire Central des Ponts et Chaussées) to test soil abrasivity. The method is described in French Standard P18-579 [21].

\section{Test Device}

The main components of the test device for determining abrasivity are the frame, the motor, the funnel tube, the metal impeller and the sample container. The device is shown schematically in Figure 8. The $750 \mathrm{~W}$ motor ensures the rotation of the axle. A metal impeller is attached to the end of the axle and is immersed in a sample container, which is cylindrical in shape with a diameter of $93 \mathrm{~mm}$ and a height of $100 \mathrm{~mm}$. The metal impeller (test specimen) has a rectangular shape with dimensions

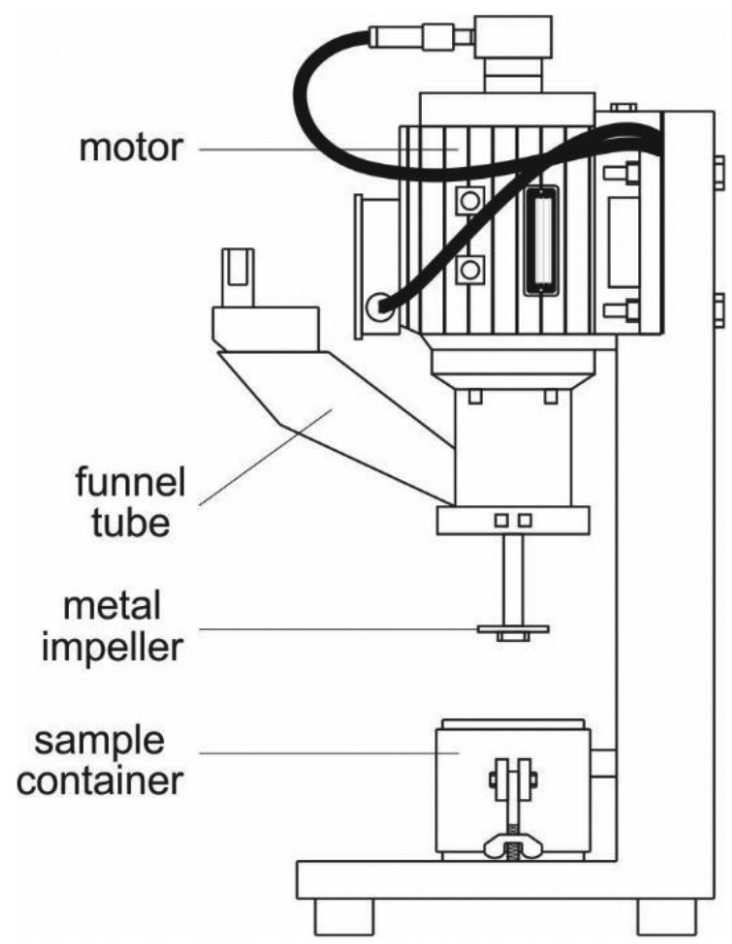

Figure 8: LCPC abrasivity testing device with main components (adapted from [18]).

$50 \mathrm{~mm} \times 25 \mathrm{~mm} \times 5 \mathrm{~mm}$. The impeller is made of standardised steel with a Rockwell hardness of HRB 60-75. The steel impeller must be replaced after each test [21].

\section{Test Sample}

The LCPC testing device is designed to investigate the abrasivity of granular materials with a grain size of 4-6.3 mm. According to French Standard P18-579 a sample of $500 \mathrm{~g} \pm 2 \mathrm{~g}$ of a dry material with a grain size of $4-6.3 \mathrm{~mm}$ is required. The required grain size of the sample is achieved by sieving. Fractions below $4 \mathrm{~mm}$ and above $6.3 \mathrm{~mm}$ must not be used in the test [21]

\section{Test Procedure}

The sample container is filled with the required granular material through the funnel tube of the testing device. The rectangular metal impeller rotates for $5 \mathrm{~min}$ in a sample container at $4,500 \mathrm{rpm}$. To determine the abrasivity of the sample material, it is necessary to determine the mass of the metal impeller before and after the test. The mass loss of a metal impeller is a measure of the abrasivity of the sample. With the loss of mass, the metal plate also deforms. The more abrasive the material sample is the greater the deformation and mass loss of the impeller [21]. Figure 9 shows schematically the metal impeller before and after the LCPC test. The main parameters of the LCPC abrasivity test are summarised in Table 3.

Table 3: Main parameters of the LCPC abrasivity test.

\begin{tabular}{cc}
\hline Parameters & Value \\
\hline $\begin{array}{c}\text { Rotational speed } \\
\left(\text { min }^{-1}\right)\end{array}$ & 4,500 \\
\hline $\begin{array}{c}\text { Sample } \\
\text { material }\end{array}$ & Soil/granular material \\
\hline $\begin{array}{c}\text { Grain size of the } \\
\text { sample (mm) }\end{array}$ & $4-6.3$ \\
\hline $\begin{array}{c}\text { Sample } \\
\text { mass (g) }\end{array}$ & $500 \pm 2$ \\
\hline $\begin{array}{c}\text { Test } \\
\text { duration (min) }\end{array}$ & 5 \\
\hline & $\begin{array}{c}\text { LCPC } \\
\text { brasivity } \\
\text { coefficient } \\
\text { (LAC) }\end{array}$ \\
Test result & $\begin{array}{c}\text { LCPC } \\
\text { breakability } \\
\text { coefficient } \\
\text { (LBC) }\end{array}$ \\
\hline & \\
&
\end{tabular}




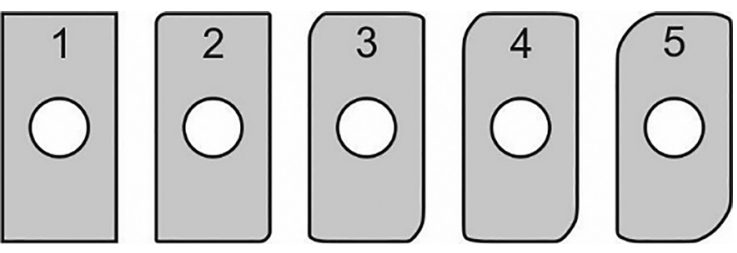

Figure 9: Schematic representation of metal impeller before and after the LCPC test: 1 new impeller, 2 not abrasive, 3 abrasive/very abrasive, 4 very abrasive and 5 extremely abrasive (adapted from [21]).

\section{Calculation of LCPC Abrasivity Coefficient}

The LCPC abrasivity coefficient (LAC) is calculated as the coefficient of mass loss of the metal impeller and the sample mass [21] as

$$
L A C=\frac{m_{0}-m}{M}
$$

where $L A C$ is the LCPC abrasivity coefficient $(\mathrm{g} / \mathrm{t}), m_{0}$ is the mass of the steel impeller before the LCPC test (g), $m$ is the mass of the steel impeller after the LCPC test ( $\mathrm{g}$ ) and $M$ is the mass of the sample material $(=0.0005 \mathrm{t})$.

The LAC for natural rocks and soils varies between 0 and 2,000 $\mathrm{g} / \mathrm{t}$. The value range can be divided into five classes. As there is a close linear correlation (Figure 10) between the LAC and the CAI index, the CAI abrasivity classification can be used [21].

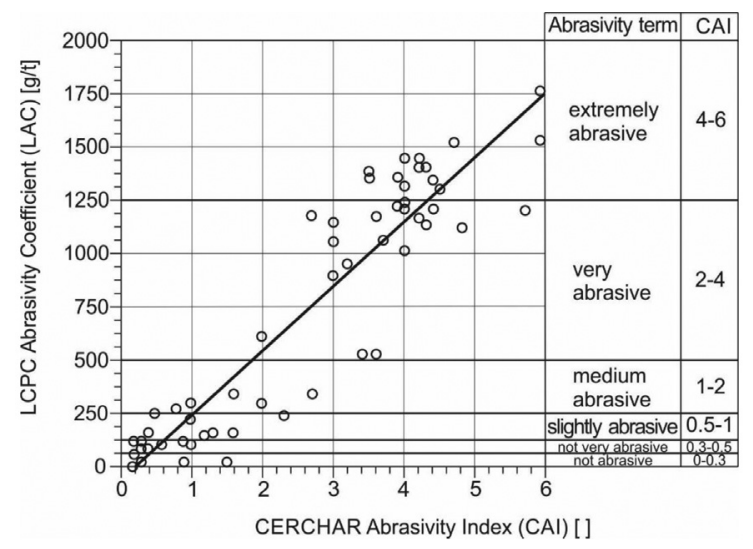

Figure 10: Correlation between LAC and CAI [21].

\section{Classification System}

The abrasivity classification system in relation to the CAI is given in Table 4 [21].
Table 4: Classification of LCPC abrasivity coefficient (LAC) in relation to the CERCHAR abrasivity index (CAI) [21].

\begin{tabular}{ccc} 
LAC $(\mathbf{g} / \mathbf{t})$ & $\begin{array}{c}\text { CAI } \\
(\mathbf{0 . 1} \mathbf{~ m m})\end{array}$ & Abrasivity term \\
\hline $0-50$ & $0-0.3$ & Not abrasive \\
\hline $50-100$ & $0.3-0.5$ & Not very abrasive \\
\hline $100-250$ & $0.5-1.0$ & Slightly abrasive \\
\hline $250-500$ & $1.0-2.0$ & (Medium) abrasive \\
\hline $500-1,250$ & $2.0-4.0$ & Very abrasive \\
\hline $1,250-2,000$ & $4.0-6.0$ & $\begin{array}{c}\text { Extremely } \\
\text { abrasive }\end{array}$ \\
\hline
\end{tabular}

\section{NTNU/SINTEF Abrasivity Tests}

NTNU/SINTEF abrasivity tests have been developed at the Norwegian University of Science and Technology in Trondheim (NTNU-Norges teknish-naturvitenskapelige universitet) in cooperation with the research organisation SINTEF (Stiftelsen for industriell og teknisk forskning).

The AV abrasivity test was developed in the 1960 s to evaluate the wear of drill bits. It provides a measure of rock abrasion or the ability to induce wear on a tungsten carbide specimen [22].

The AVS abrasivity test was developed between 1980 and 1983 based on the AV test. The purpose of the test is to evaluate the tool life of mechanised rock TBM tunnelling. Compared to the AV test, the AVS test differs in the specimen material and the duration of the test. The AVS is a measure of rock abrasion or the ability to induce wear on cutter ring steel [22].

Soil abrasion test (SAT ${ }^{\mathrm{TM}}$ ) was introduced in 2005 to evaluate the tool life of mechanised TBM tunnelling in soft ground and in soil. The test is a further development of the NTNU/SINTEF abrasion tests for rock. The test device for the soil abrasion test is identical to the device for AV and AVS abrasivity tests. The difference is in the sample material [23].

The abrasivity tests are quite similar, except that the AV test measures the wear of a tungsten carbide specimen and the AVS and SAT ${ }^{\mathrm{TM}}$ tests measure the wear of a specimen made of TBM cutter ring steel $[22,23]$. 


\section{Device}

The device is identical for all three abrasivity tests. In the individual tests, the grain size of the rock or soil sample and the material of the test specimen are different.

The device, which is shown schematically in Figure 11, consists of a drive, a rotating steel disc, a test specimen, a weight, a sample material feeder and a suction device.

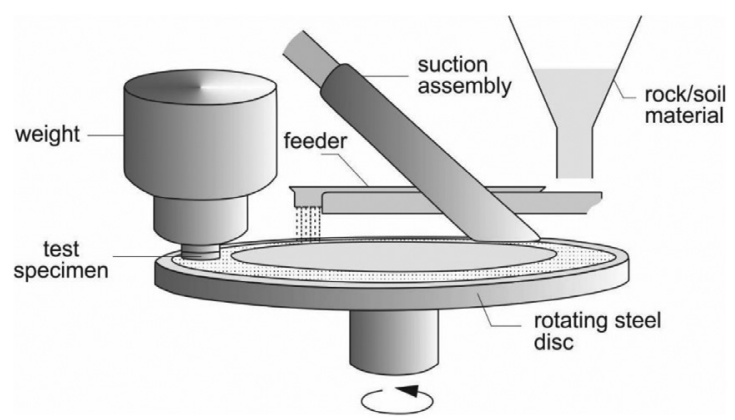

Figure 11: NTNU/SINTEF abrasivity device (adapted from [22]).

\section{Test Specimen}

The material of the specimen in the AV test is tungsten carbide. The specimen in the AVS and SAT $^{\mathrm{TM}}$ tests is steel taken from the TBM cutter ring. The test specimen is cuboidal with a rounded surface in shape. The length of the test specimen for the AV and AVS tests is $30 \mathrm{~mm}$, the width is $10 \mathrm{~mm}$ and the radius is $15 \mathrm{~mm}$. The test specimen for the AV and AVS tests is shown in Figure 12.

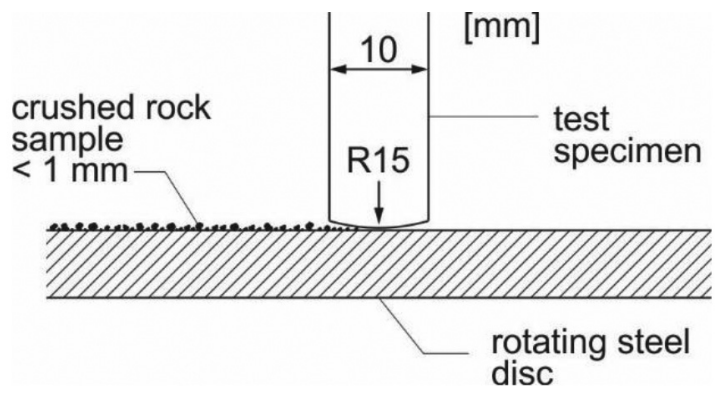

Figure 12: Test specimen for rock abrasivity test AV and AVS (adapted from [23]).

The length of the test specimen for the SAT ${ }^{\mathrm{TM}}$ test is $30 \mathrm{~mm}$, the width $20 \mathrm{~mm}$ and the radius $15 \mathrm{~mm}$. The test specimen for the SAT ${ }^{\mathrm{TM}}$ test is shown in Figure 13. During the rotation of the steel plate the rock or soil sample passes under the rounded part of the stationary test specimen.

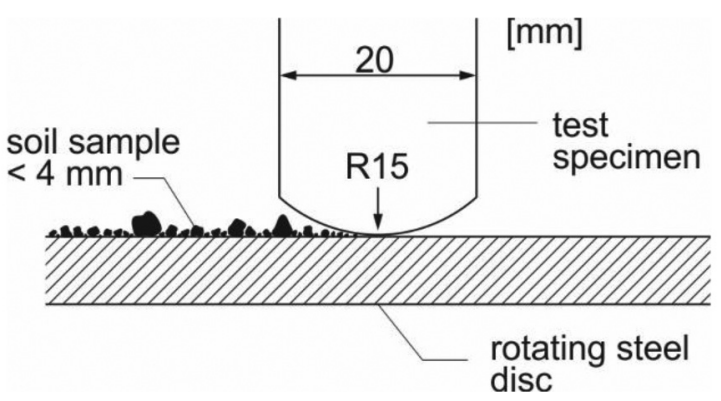

Figure 13: Test specimen for soil abrasivity test SATM (adapted from [23]).

\section{Sample Material}

Crushed rock powder with a grain size of less than $1 \mathrm{~mm}$ is used for the AV and the AVS tests. Therefore the sample material has to be crushed and/or ground and sieved before the test.

For the SAT ${ }^{\mathrm{TM}}$ test, a dry and gently crushed soil sample with a grain size of less than $4 \mathrm{~mm}$ is used. The SAT ${ }^{\mathrm{TM}}$ test is applicable for the investigation of clay, silt and sand fractions [23].

\section{Test Procedure}

Abrasivity tests AV, AVS and SAT ${ }^{\mathrm{TM}}$ represent the time-dependent abrasion of tungsten carbide (AV) or TBM cutter ring steel (AV, SAT $\left.{ }^{\mathrm{TM}}\right)$, caused by rock powder or soil grains. The same test device is used for all the three tests.

A circular steel disc with a circumference of $1,000 \mathrm{~mm}$ (318.3 mm diameter) is set horizontally and rotates around its axis at a speed of $20 \mathrm{rpm}$. A rock or soil sample falls via the feeder onto the upper outer part of the steel disc and forms a material belt. The mass flow rate of the sample material is approximately $80 \mathrm{~g} / \mathrm{min}$. In front of the feeder (in the direction of rotation) a test specimen is mounted and loaded with a normal force of $100 \mathrm{~N}$. The test specimen is firmly clamped and is stationary during the test. The contact between the test specimen and the sample material causes abrasive wear of the test specimen. A suction device is installed behind the feeder (in the direction of rotation) to remove the sample material from 
the steel disc. This allows the test specimen to remain in contact with new material during the entire test. The length of the path that the test specimen travels on the sample material is $100 \mathrm{~m}$ for the AV test and $20 \mathrm{~m}$ for the AVS and SAT $^{\mathrm{TM}}$ test $[22,23]$.

The duration of the AV test is 5 min or 100 disc rotations, that is, $100 \mathrm{~m}$.

The duration of the AVS and SAT ${ }^{\mathrm{TM}}$ test is $1 \mathrm{~min}$ or 20 disc rotations, that is, $20 \mathrm{~m}$.

The tests AV, AVS and SAT ${ }^{\mathrm{TM}}$ are normally carried out on 2-4 test specimens. The deviation is very small and should not exceed $5 \mathrm{mg}$ of weight loss if the test is performed correctly. The reported AV, AVS and SAT ${ }^{\mathrm{TM}}$ values are the main values of 2-4 parallel tests [22]. The main parameters of the NTNU/SINTEF abrasivity tests are listed in Table 5.

Table 5: Main parameters of the NTNU/SINTEF abrasivity tests.

\begin{tabular}{|c|c|c|c|}
\hline Parameters & \multicolumn{3}{|c|}{ Value } \\
\hline Load (N) & \multicolumn{3}{|c|}{100} \\
\hline $\begin{array}{c}\text { Rotational } \\
\text { speed }\left(\mathrm{min}^{-1}\right)\end{array}$ & \multicolumn{3}{|c|}{20} \\
\hline $\begin{array}{l}\text { Material mass } \\
\text { flow }(\mathrm{g} / \mathrm{min})\end{array}$ & \multicolumn{3}{|c|}{80} \\
\hline & $\mathrm{AV}$ & AVS & $\mathrm{SAT}^{\mathrm{TM}}$ \\
\hline $\begin{array}{l}\text { Test duration } \\
\text { (min) }\end{array}$ & 5 & 1 & 1 \\
\hline $\begin{array}{l}\text { Sample } \\
\text { material }\end{array}$ & $\begin{array}{l}\text { Crushed } \\
\text { rock } \\
\text { powder }\end{array}$ & $\begin{array}{l}\text { Crushed } \\
\text { rock } \\
\text { powder }\end{array}$ & soil \\
\hline $\begin{array}{l}\text { Grain size of } \\
\text { the sample } \\
(\mathrm{mm})\end{array}$ & $<1$ & $<1$ & $<4$ \\
\hline $\begin{array}{c}\text { Test specimen } \\
\text { material }\end{array}$ & $\begin{array}{c}\text { Tungsten } \\
\text { carbide }\end{array}$ & $\begin{array}{l}\text { Cutter } \\
\text { ring steel }\end{array}$ & $\begin{array}{c}\text { Cutter } \\
\text { ring } \\
\text { steel }\end{array}$ \\
\hline Test result & AV value & AVS value & $\begin{array}{l}\text { SAT }^{\mathrm{TM}} \\
\text { value }\end{array}$ \\
\hline
\end{tabular}

\section{$A V, A V S$ and $S A T^{T M}$ values}

To determine the abrasivity, it is necessary to measure the mass of the test specimen before and after the test. The loss of mass of the test specimen is a measure of the abrasivity of the rock or soil sample.

\section{Classification System}

The classification given in Table 6 is based on the distribution of the recorded results of the 2,621 samples used to determine AV, 1,590 samples tested to determine AVS and 254 abrasivity measurements on soil samples for the determination of $\mathrm{SAT}^{\mathrm{TM}}$. The reason for proposing only three classification categories for SAT ${ }^{\mathrm{TM}}$ is the relatively small amount of data compared to AV and AVS measurements [23].

Table 6: Classification of rock and soil abrasion on tungsten carbide (AV) and cutter steel (AVS, SAT TM) test specimen [22].

\begin{tabular}{cccc} 
Abrasion & AV (mg) & AVS (mg) & SAT $^{\mathrm{TM}} \mathbf{( m g )}$ \\
\hline $\begin{array}{c}\text { Extremely } \\
\text { high }\end{array}$ & $\geq 58.0$ & $\geq 44.0$ & \\
\hline Very high & $42.0-57.9$ & $36.0-44.0$ & \\
\hline High & $28.0-41.9$ & $26.0-35.9$ & $\geq 22.0$ \\
\hline Medium & $11.0-27.9$ & $13.0-25.9$ & $7.0-22.0$ \\
\hline Low & $4.0-10.9$ & $4.0-12.9$ & $\leq 7.0$ \\
\hline Very low & $1.1-3.9$ & $1.1-3.9$ & \\
\hline $\begin{array}{c}\text { Extremely } \\
\text { low }\end{array}$ & $\leq 1.0$ & $\leq 1.0$ & \\
\hline
\end{tabular}

\section{RIAT Abrasivity Test}

The RIAT was developed at the Norwegian University of Science and Technology in Trondheim (NTNU-Norges teknish-naturvitenskapelige universitet). The aim of the test is to imitate the wear behaviour of TBM cutter discs in mechanised tunnelling.

The rock and soil abrasivity tests described previously (CERCHAR, LCPC, NTNU) use sliding and impact contacts to induce wear. In contrast to the tests described above, the RIAT is based on a rolling contact that is more realistic for assessing disc cutter wear. Another difference between some abrasivity tests and the RIAT is that these tests use crushed rock samples instead of intact samples [24].

\section{Device}

The RIAT device, schematically shown in Figure 14, consists of two interchangeable minia- 
ture rolling discs that roll over and penetrate the surface of an intact rock sample. Rotation, torque and vertical thrust are provided by a drive unit [24].

The rolling diameter or the distance between two miniature discs is $60 \mathrm{~mm}$. The diameter of the miniature rolling disc is $30 \mathrm{~mm}$ and the tip

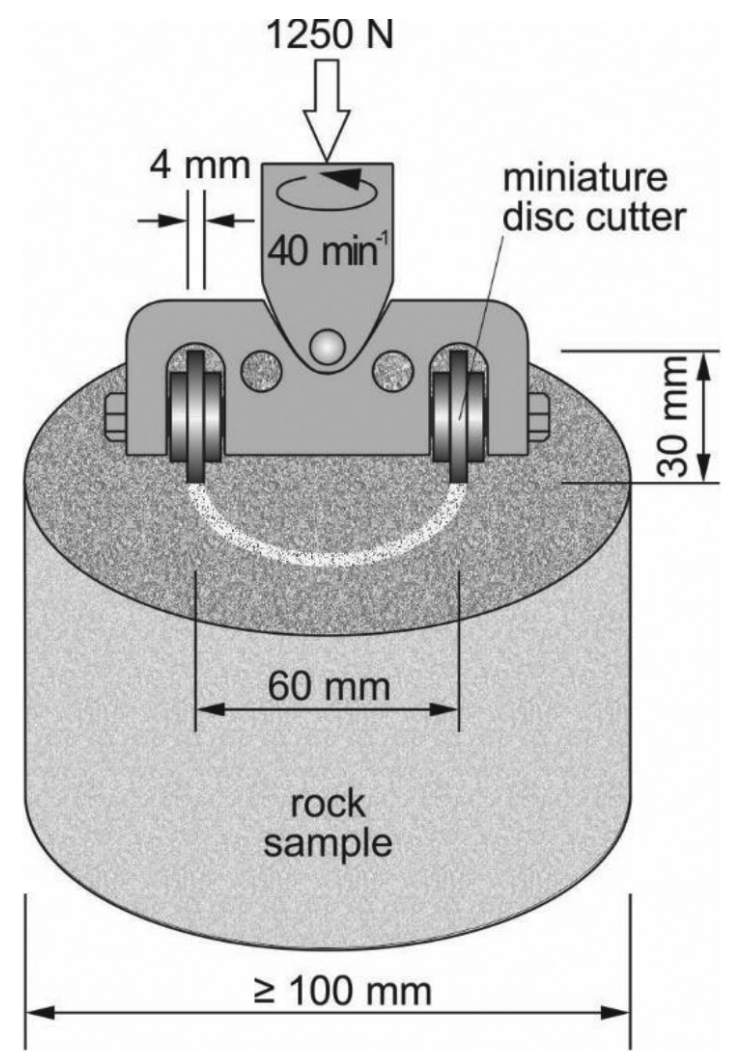

Figure 14: RIAT device (adapted from [24]).

width is $4 \mathrm{~mm}$ [24].

\section{Test Sample}

The test sample is intact rock that can have any shape. It is recommended that the surface of the rock sample is smooth and horizontal. Usually a circular rock core is used for the test. In such a case the minimum diameter of the rock sample is $100 \mathrm{~mm}$ [24].

\section{Miniature Rolling Discs}

Miniature rolling discs are made of hot work tool steel AISI type H13, which is normally used for the actual TBM cutter rings. The miniature discs have a constant tip width of $4 \mathrm{~mm}$. The diameter of the discs is $30 \mathrm{~mm}$. The Rockwell hardness of the steel is HRC $50 \pm 1$ [24].

\section{Test Procedure}

The test is carried out in such a way that two miniature discs roll over a rock sample under the influence of the normal thrust of $1,250 \mathrm{~N}$ at a speed of $40 \mathrm{rpm}$ and a center distance of $60 \mathrm{~mm}$. The test parameters were determined in relation to real cutter parameters in mechanised TBM tunnelling in hard rock. The test duration is 30 min. Rock dust and debris formed during the test should be removed from the surface of the rock to be tested to ensure that the miniature rolling disc is in constant contact with the rock sample. A combination of compressed air and suction is used for this purpose [24]. The main parameters of the RIAT are listed in Table 7.

Table 7: Main parameters of the RIAT [24].

\begin{tabular}{cc} 
Parameters & Value \\
\hline Thrust (N) & 1,250 \\
\hline $\begin{array}{c}\text { Rolling velocity } \\
\left(\text { min }^{-1}\right)\end{array}$ & 40 \\
\hline Test duration (min) & 30 \\
\hline $\begin{array}{c}\text { Disc hardness } \\
\text { (HRC) }\end{array}$ & $50 \pm 1$ \\
\hline Sample material & Rock (smooth surface) \\
\hline RIAT abrasivity index \\
(RIAT $)$
\end{tabular}

\section{Determination of the RIAT Abrasivity Index and the RIAT Indentation Index}

The result of RIAT is the RIAT abrasivity index $\left(\right.$ RIAT $_{\mathrm{a}}$ ) and the RIAT indentation index (RIAT). RIAT $_{a}$ is defined as the mass loss of the miniature rolling disc, measured in milligrams after the test. A representative mean value is determined by at least three tests [24].

RIAT $_{i}$ is defined as the mean value of 10 evenly distributed measurements of the penetration depth of the miniature rolling disc into the rock 
surface in $1 / 100 \mathrm{~mm}$. The RIAT ${ }_{i}$ value is an indication of the penetration resistance of the rock or the hardness of the rock surface [24]. In the study reported by Macias et al. [24], eight types of rocks were selected for the RIAT. At least three parallel tests were carried out for each rock type, so that a total of 29 were performed. The lowest and highest RIAT ${ }_{\mathrm{a}}$ of the test performed is 3 for limestone and 104 for quartzite. The lowest and highest RIAT $_{i}$ of the test carried out is 5 for quartzite and 380 for limestone.

As the study shows, RIAT and RIAT $_{i}$ are inversely correlated. A higher RIAT means a lower RIAT $_{i}$ [24].

Due to a small number of tests carried out, the classification for the RIAT has not yet been determined.

\section{Gouging Abrasion Test}

The gouging abrasion test was developed to assess rock abrasivity in environments where high stress loads are expected at high speeds and at different angles of incidence. These conditions can be achieved in many mineral processing and mining equipment. Abrasion under such conditions causes considerable wear of the tool material [2].

\section{Apparatus}

A gouging abrasion test simulates very high stress abrasion under high-energy impact conditions [2].

The rock sample with a rectangular shape and flat surface is clamped in the sample holder. A steel pin with a $90^{\circ}$ angle is attached to the end of the pendulum arm. The length of the pendulum arm is such that the steel pin forcibly touches the surface of the rock sample as it swings past, creating a scratch along the entire length of the rock sample [2].

The apparatus is shown schematically in Figure 15. The rock sample is held securely in the sample holder, which can be moved vertically and horizontally by means of the transfer screw or spring mechanism. The wear tool is rigidly positioned in the tool holder of the pendulum arm, which is released from its working position. The steel pin scratches over the rock

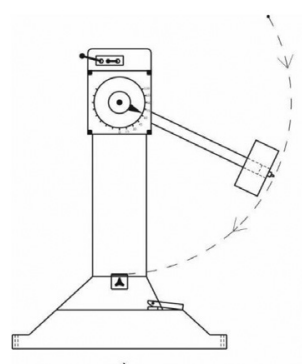

a)

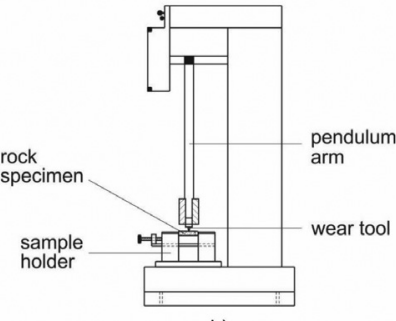

b)
Figure 15: Gouging abrasion test apparatus. (a) Front view. (b) Side view (adapted from [2]).

surface as it moves. The pendulum has $300 \mathrm{~J}$ available impact energy. The impact speed is $5.2 \mathrm{~m} / \mathrm{s}[2]$.

\section{Test Sample}

The rock sample has a rectangular shape with a length of $80 \pm 0.5 \mathrm{~mm}$. Due to irregularities in the samples, the width can vary and take on values between 25 and $50 \mathrm{~mm}$. The thickness of the sample is between 10 and $16 \mathrm{~mm}$. The examined surface of the rock sample is flat and smooth, as is the case with a diamond saw cut. This eliminates the influence of the different surface roughness of the rock sample on the test results [2].

\section{Wear Tool}

According to Golovanevskiy and Bearman [2], a wear tool of Rockwell hardness HRC 40-42 is recommended for the gouging abrasion test. The wear tool is made of steel AS 1444/4340-Y. The tool is $25 \mathrm{~mm}$ long with a diameter of $9.375 \pm 0.25 \mathrm{~mm}$. The tool pin has a $90^{\circ}$ angle.

\section{Test Procedure}

The prepared rock sample is placed in the sample holder. It is necessary to ensure the horizontal surface of the sample to be examined. The apparatus is equipped with a screw device for fine adjustment of the sample height and a spring system for rapid horizontal movement [2].

The wear tool is carefully inserted into the wear tool holder of the pendulum arm. When the pendulum arm is fully vertical, the pin of the wear tool is directed vertically into the test surface of the rock sample in the holder. At this point, there are a few millimetres of clearance 


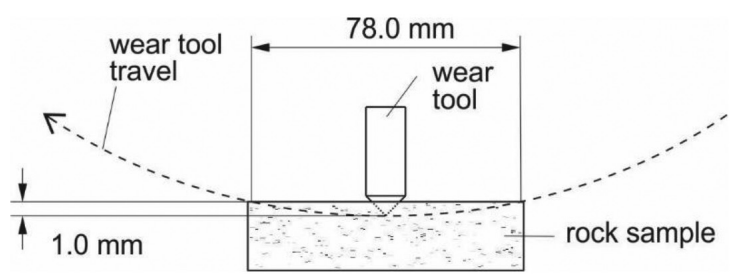

Figure 16: Wear contact between tool and rock sample (adapted from [2]).

between the pin of the wear tool and the surface of the rock sample [2].

The sample holder is then lifted together with the sample via a screw assembly to achieve a slight contact between the surface of the rock sample and the wear tool pin [2].

The pendulum arm is lifted to its initial position. The sample holder with the rock sample is then raised by $1.0 \mathrm{~mm}$. The accuracy is measured with a micrometre. This allows a $1.0-\mathrm{mm}$ deep wear tool cut in the rock sample. The wear tool is allowed to make a 78-mm long arcshaped cut on the surface of the rock sample, as shown in Figure 16 [2].

The pendulum arm is released. The pin of a wear tool produces a cut or scratch when it moves over a rock surface. The pendulum arm continues to move to the highest point of the path even as it passes the rock sample. When the pin of the wear tool is no longer in contact with the rock surface after the first swing, the sample holder moves quickly in a horizontal direction perpendicular to the plane of the pendulum motion via the spring mechanism. Due to this displacement of the rock sample, the wear tool and the rock surface no longer come into contact when the arm is moved back. The sample after several tests is schematically shown in Figure 17. When the pendulum stops, the wear tool is removed from the holder and the pin wear is measured. The rock sample holder is returned to its original working position and is moved about $5 \mathrm{~mm}$ to provide a fresh surface in the rock sample for further testing. The described procedure is valid for a single test run. For each further test run, a wear tool with an unused pin is inserted into the wear tool holder of the pendulum arm and the procedure described above is repeated [2]. The main parameters of the gouging abrasion test are listed in Table 8.

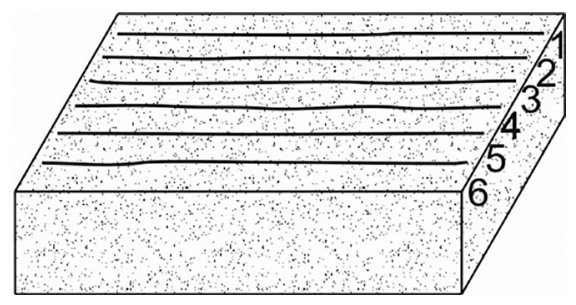

Figure 17: Rock sample after testing (schematic). Numbers 1-6 represent individual scratches from the test (adapted from [2]).

Table 8: Main parameters of the gouging abrasion test.

\begin{tabular}{cc} 
Parameters & Value \\
\hline Impact energy (J) & 300 \\
\hline $\begin{array}{c}\text { Wear tool hardness } \\
\text { (HRC) }\end{array}$ & $40-42$ \\
\hline $\begin{array}{c}\text { Test scratch length } \\
\text { (mm) }\end{array}$ & 78 \\
\hline Sample material & Rock (smooth surface) \\
\hline Test result & Gouging abrasion index \\
(Gi)
\end{tabular}

\section{Gouging Abrasion Index}

The gouging abrasion index (Gi) is determined in the same way as the CAI, that is, the average distance of pin wear in millimetres multiplied by a factor of 10 [2].

For the representative value of the $\mathrm{Gi}$, several tests should be carried out on a single rock sample. In practice, it is advisable to perform at least three test runs on a single rock sample, using a new wear tool and a fresh wear surface of the rock sample. This can be done with three wear tools and a 25-30-mm wide rock sample [2].

\section{Conclusion}

The wear of tools and equipment during technological processes in geotechnology and mining is associated with high economic costs. On the one hand, there are the material costs associated with the replacement of worn tools or equipment, and on the other hand, there are the costs of downtime of the work process. The abrasivity is directly related to tool wear. Knowledge of the tribological system and wear mechanisms helps us to understand this com- 
plex problem. However, once the basics are known and the problem is understood, the next step can be taken, that is, the attempt to prevent it at least partially and the possibility to model or predict tool wear. It is not possible to prevent the abrasive wear of geotechnology and mining application tools in such an aggressive environment as the geological one. However, with the knowledge of the problem it is possible to develop materials that build tools. Every small step to improve the wear resistance of a material is very valuable. The four main components of the tribological system are the geological material, surrounding medium, tools and load type. It should be considered that the first two components mentioned above cannot be modified. However, the tool (and the material it is made of) and the load type can be modified. Any change to the component of the tribological system is reflected in the wear. Therefore, a detailed study of the wear mechanisms for a specific technological process (be it mechanised tunnelling, drilling, crushing or grinding of mineral raw materials) should be carried out, and on this basis an optimisation of the geometry and material of the tool in dynamic contact with the geological material and the type of loading should be carried out.

Two factors are of particular importance for a comprehensive understanding of tool wear. These are the wear rate and the mode of wear. In a comprehensive approach, the wear rate can be defined as the first stage and the wear mode as the second stage of wear investigation. Laboratory test methods for assessing the abrasivity of rocks and soils are important because they allow the wear rate of tools that interact dynamically with the abrasive geological material to be determined. The wear rate can be determined immediately after the test is performed, for example, by weighing the loss of mass of the test specimen or by microscopic examination of the pin wear, depending on the test set-up. However, the second stage of the comprehensive approach is to determine the mode of wear, which can be derived from the first stage.

This article presents a review of the laboratory tests to assess the abrasivity of rocks and soils, which are useful in the field of geotechnology and mining. These abrasivity tests can help us to gain a comprehensive understanding of tool wear, especially in the first stage, for determination of the wear rate. However, it is recommended that starting from the first stage, the study of wear be continued in the second stage, which is concerned with determining the mode of wear. Compared to the first stage, the second stage is more demanding and time-consuming, as it requires interdisciplinary material knowledge and several individual geochemical and metallurgical investigations at the microscopic level. A comprehensive approach to the investigation of wear is the basis for the development of wear resistant tools and models for the prediction of tool life in individual areas of geotechnology and mining.

\section{References}

[1] Petrica, M., Painsi, M., Badisch, E., Peinsitt, T. (2014): Wear Mechanisms on Martensitic Steels Generated by Different Rock Types in Two-Body Conditions. Tribology Letters, 53(3), pp. 607-616, DOI: 10.1007/ s11249-014-0298-z.

[2] Golovanevskiy, V.A., Bearman, R.A. (2008): Gouging abrasion test for rock abrasiveness testing. International Journal of Mineral Processing, 85(4), pp. 111-120, DOI: 10.1016/j.minpro.2007.08.004.

[3] BBT Brenner Base Tunnel [online]. Galleria di Base del Brennero - Brenner Basistunnel BBT SE [cited 3/5/2020]. Available on: https://www.bbt-se.com.

[4] Marti Group [online, cited 3/5/2020]. Available on: https://www.marti.com.

[5] Robbins [online]. The Robbins company [cited 3/5/2020]. Available on: https://www. therobbinscompany.com.

[6] Krauze, K., Bołoz, Ł., Wydro, T. (2015): Parametric Factors for the Tangential-Rotary Picks Quality Assessment. Archives of Mining Sciences, 60(1), pp. 265-281, DOI: 10.1515/amsc-2015-0018.

[7] Boart Longyear [online]. Boart Longyear company [cited 3/5/2020]. Available on: https://www. boartlongyear.com.

[8] Varel [online]. Varel International Energy Services [cited 3/5/2020]. Available on: http://www. vareloilandgas.com.

[9] Tkalich, D., Yastrebov, V.A., Cailletaud, G., Kane, A. (2017): Multiscale modeling of cemented tungsten carbide in hard rock drilling. International Journal of Solids and Structures, 128, pp. 282-295, DOI: 10.1016/j.ijsolstr.2017.08.034. 
[10] Yahiaoui, M., Paris, J.Y., Denape, J., Dourfaye, A. (2015): Multiscale and Comparative Study of WCCo Tribological Behavior. In: Procédés et Génie civil: 27ème Journées Internationales Francophones de Tribologie: JIFT, Nantes, France, Do, M.T., Cérézo, V., Kapsa, P. (eds.). Presses des Mines: Paris, pp. 219-226.

[11] Cavpower [online, cited 3/5/2020]. Available on: https://www.cavpower.com.

[12] RWE [online]. RWE Group [cited 3/5/2020]. Available on: https://www.group.rwe.

[13] Blumaq [online, cited 3/5/2020]. Available on: https://www.blumaq.com.

[14] Sandvik [online, cited 3/5/2020]. Available on: https://www.rocktechnology.sandvik.

[15] Metso [online, cited 3/5/2020]. Available on: https://www.metso.com.

[16] Energosteel [online, cited 3/5/2020]. Available on: https://energosteel.com.

[17] Alber, M., Yarah, O., Dahl, F., Bruland, A., Käsling, H., Michalakopoulos, T.N., Cardu, M., Hagan, P., Aydin, H., Özarslan, A. (2013): ISRM Suggested Method for Determining the Abrasivity of Rock by the CERCHAR Abrasivity Test. Rock Mechanics and Rock Engineering, 47(1), pp. 261-266, DOI: 10.1007/s00603-0130518-0.

[18] Käsling, H., Thuro, K. (2010): Determining rock abrasivity in the laboratory. In: Rock mechanics in civil and environmental engineering: proceedings of the European Rock Mechanics Symposium (EUROCK) 2010, Lausanne, Switzerland, Zhao, J. (ed.). CRC Press: Leiden.

[19] Plinninger, R., Käsling, H., Thuro, K., Spaun, G. (2003): Testing conditions and geomechanical properties influencing the CERCHAR abrasiveness index (CAI) value. International Journal of Rock Mechanics \& Mining Sciences, 40(2), pp. 259-263, DOI: 10.1016/S1365-1609(02)00140-5.

[20] Aydin, H. (2019): Investigating the effects of various testing parameters on Cerchar abrasivity index and its repeatability. Wear, 418-419, pp. 61-74, DOI: 10.1016/j.wear.2018.11.001.

[21] Thuro, K., Singer, J., Käsling, H., Bauer, M. (2006): Soil Abrasivity Assessment Using the LCPC Testing Device. Felsbau, 24(6), pp. 37-45, DOI: 10.1201/ NOE0415444019-c103.

[22] Dahl, F., Bruland, A., Jakobsen, P.D., Nilsen, B., Grøv, E. (2012): Classification of properties influencing the drillability of rocks, based on the NTNU/ SINTEF test method. Tunnelling and Underground
Space Technology, 28, pp. 150-158, DOI: 10.1016/j. tust.2011.10.006.

[23] Jakobsen, P.D., Bruland, A., Dahl, F. (2013): Review and assessment of the NTNU/SINTEF Soil Abrasion Test $\left(\mathrm{SAT}^{\mathrm{TM}}\right.$ ) for determination of abrasiveness of soil and soft ground. Tunnelling and Underground Space Technology, 37, pp. 107-114, DOI: 10.1016/j. tust.2013.04.003.

[24] Macias, F.J., Dahl, F., Bruland, A. (2016): New Rock Abrasivity Test Method for Tool Life Assessments on Hard Rock Tunnel Boring: The Rolling Indentation Abrasion Test (RIAT). Rock Mechanics and Rock Engineering, 49(5), pp. 1679-1693, DOI: 10.1007/ s00603-015-0854-3. 
